\title{
EU Citizenship as a Means of Broadening the Application of EU Fundamental Rights: Developments and Limits
}

\author{
Katerina Kalaitzaki*
}

\section{Introduction}

The EU is no longer an organisation which merely pursues economic objectives but is also evolving towards a more political and constitutionalised Union. The article supports the idea that the political integration in the domain of EU fundamental rights is primarily evolving through a 'triangular', inter-connected system of protection, including the constructivist transformation of EU citizenship, the institutionalised developments of EU law, ${ }^{1}$ and the protection of fundamental rights as general principles of EU law. Yet major components of a comprehensive and all-embracing fundamental rights policy are still absent, which is even more perceptible during periods of crisis, such as the recent financial crisis, where the gaps in citizens' rights protection became evident due to the difficulties encountered in challenging the consequences of the conditionality imposed. ${ }^{2}$ This deficient protection largely derived from the restricted scope of application of fundamental rights under the Charter, its unstable judicial interpretation, and in turn from the unwillingness of the Court to rule on complex financial cases. The financial crisis and its mechanisms constitute a useful case study from which to assess the modern 'triangular' protection of rights and encourage interest in assessing new legal paths to reinforce it.

Although EU citizenship has not played a substantial role in the financial crisis, this article suggests that it is not constrained to its current, 'confined'

* Early Career Fellow in European Union Law, Edinburgh Law School.

1 Kostakopoulou, D. (2005). Ideas, Norms and European Citizenship: Explaining Institutional Change. The Modern Law Review 68 (2), pp. 233-267, 250 et seq.

2 Menéndez, A.J. (2013). The Existential Crisis of the European Union. German Law Journal 14 (5), pp. $453^{-} 5^{26,} 455$. 
form, since it is designed to encounter constant evolution and progress. ${ }^{3}$ Its constructive character culminated in the judicially developed 'substance of the rights' doctrine, which has substantially altered the architecture of EU fundamental rights protection towards including purely internal violations within the Union's scope, if they amount to emptying Union citizenship rights of their substantive meaning. When placed within a new jurisdictional test, the doctrine can arguably fill the gaps of the current protection system in an effort to link EU fundamental and citizenship rights and propose an alternative, more effective use of rights.

\section{Setting the Scene: Legal Characteristics of the 'Triangular' Fundamental Rights Protection System}

The first corner of the 'triangle' is the legal concept of Union citizenship, ${ }^{4}$ which constituted a decisive step towards a constitutionalised Union; ${ }^{5}$ although a relevant personal status had clearly matured long before its formal incorporation in the Maastricht Treaty. ${ }^{6}$ The list of rights provided under Article 20 TFEU, although non-exhaustive, fell short of establishing the full range of modern citizenship rights, ${ }^{7}$ since no legal connection was declared with fundamental rights. The Commission however, defined EU citizenship as a dynamic concept which should always reflect 'the aims of the Union, [...] stemming from the gradual and coherent development of the Union's political, economic and

3 Union citizenship, Contributions by the Commission to the Intergovernmental Conference SEC (91) 500 Bull EC Supp. 2/91, p. 87; Closa, C. (1992). The Concept of Citizenship in the Treaty on European Union. Common Market Law Review 29 (6), pp. 1137-1169, 1167.

4 Kostakopoulou, D. (2005). Ideas, Norms and European Citizenship, cit., p. 250.

5 Wiener, A. (1999). The Constructive Potential of Citizenship: building European Union. Policy \& Politics 27 (3), pp. 271-293.

6 Kochenov, D., and Plender, R. (2012). EU Citizenship: From an Incipient Form to an Incipient Substance? The Discovery of the Treaty Text. European Law Review 37, pp. 369-396; Welge, R. (2015). Union Citizenship as Demoi-cratic Institution: Increasing the EU's Subjective Legitimacy Through Supranational Citizenship. Journal of European Public Policy 22 (1), pp. 56-74; Kostakopoulou, T. (2010). Citizenship, Identity and Immigration in the European Union: between Past and Future. Manchester: Manchester University Press; O'Leary, S. The relationship between Community citizenship and the protection of fundamental rights in Community law. Common Market Law Review 32 (2), pp. 519-554, 519.

7 European Parliament (1991). Bindi Report on Union Citizenship. Doc. A 3-0139/91, 23 May 1991; Closa, C. (1995). Citizenship of the Union and Nationality of Member States. Common Market Law Review 32 (2), pp. 487-518, 49o. 
social dimension'. It has indeed proved to be of 'constructivist' nature, especially through the Court of Justice's case law, by deepening European integration, based on a federal logic, while broadening the potential impact on EU fundamental rights. Namely, after Martínez Sala,${ }^{9}$ EU citizenship demonstrated a shift away from 'economic and market citizens', to a social and political dimension, ${ }^{10}$ while establishing protection against discrimination based on nationality and a free-standing right to move and reside freely. ${ }^{11}$ The constructivist nature of EU citizenship culminated with the inclusion of new, unwritten rights into the concept, through the 'substance of the rights doctrine'.

Regardless of the influence exerted by EU citizenship in forming current policies, a significant role was also played by the 'effects of institutional interaction,', 12 such as the Charter, whose list of rights is far more extensive, as it reunites a wide range of rights and freedoms - including socioeconomic rights - which have been violated the most during the financial crisis..$^{13}$ On the contrary, considering the nature of the two concepts, the list under EU citizenship might currently be limited, but its constructivist nature arguably allows for expansion of the 'inter alia list' under Article 20 TFEU. Therefore,

8 Union citizenship, Contributions by the Commission to the Intergovernmental Conference, cit., p. 87 .

9 Court of Justice, judgment of 12 May 1998, case C-85/96, María Martínez Sala v. Freistaat Bayern.

10 O'Leary, S. (1999). Putting Flesh on the Bones of European Union Citizenship. European Law Review 24 (1), pp. 68-79; Kochenov, D. (2009). Ius Tractum of Many Faces: European Citizenship and the Difficult Relationship between status and Rights. Columbia Journal of European Law 15 (1), pp.169-237, 173 et seq.

11 Court of Justice, judgment of 7 September 2004, case C-456/o2, Trojani; Court of Justice, judgment of 20 September 2001, case C-184/99, Grzelczyk; Barnard, C. (2013). The Substantive Law of the EU: The Four Freedoms, Oxford: Oxford University Press; Court of Justice, judgment of 17 September 2002, case C-413/99, Baumbast and R, para. 83; Court of Justice, judgment of 26 October 2006, case C-192/05, Tas-Hagen and Tas; Opinion of AG Kokott delivered on 30 March 2006, case C-192/o5, Tas-Hagen Tas, para. 33.

12 Kostakopoulou, D. (2005). Ideas, Norms and European Citizenship, cit., p. 264; Liisberg, J.B. (2001). Does the EU Charter of Fundamental Rights Threaten the Supremacy of Community Law? Article 53 of the Charter: a fountain of law of just an inkblot. Jean Monnet Working Paper, no. 4/o1, p. 7; Lenaerts, K. (2012). Exploring the Limits of the EU Charter of Fundamental Rights. European Constitutional Law Review 8 (3), pp. 375-403; Arestis, G. (2013). Fundamental Rights in the EU:Three years after Lisbon, the Luxembourg Perspective. College of Europe Cooperative Research Papers No. 2/2013, p. 2; Schneider, C.B. (2014). The evolution of the first Bill of Rights of the European Union and its position within the constellation of national and regional fundamental rights protection systems. Bridging Europe Working Paper, p. 2 et seq.

13 Peers, S., Hervey, T., Kenner, J., and Ward, A., eds. (2014). The EU Charter of Fundamental Rights A Commentary. London: Bloomsbury Publishing. 
while the list of rights under the Charter adequately incorporates the rights violated during the financial crisis, the precise extent of Union citizenship rights cannot be clearly defined from a strictly textual perspective. However, it is generally believed that the essence of EU citizenship is much broader than the list provided by Article $2 \mathrm{O}(2) \mathrm{TFEU}$, in the broader sense of what supranational citizenships entail. ${ }^{14}$

The third piece of the EU triangular system is the protection of fundamental rights as general principles of EU law, many of which are unwritten and judgemade, but the majority of which have been codified in the Treaties over time. ${ }^{15}$ They inter alia assist with judicial interpretations and legal reviews, ${ }^{16}$ but more importantly, they are largely used to fill legal gaps where relevant EU laws are lacking or do not provide a concrete answer. ${ }^{17}$ It can thus be argued that general principles are both institutional and constructive in nature, since they are enshrined in the Treaty, but the Court regularly recognises new rights as falling within the 'general principles umbrella', under Article 2 TEU.

Nevertheless, the effectiveness and potential use of the instruments in a crisis, largely depends on their material and/or personal scope of application and the existence of any legal restrictions. The scope of EU citizenship was largely based on the logic of economic growth, ${ }^{18}$ which has arguably diminished its essence and the attempts made in the Maastricht Treaty to connect it with the citizen. ${ }^{19}$ However, the CJEU has identified an increasing number

14 Kochenov, D. (2017). On Tiles and Pillars: EU Citizenship as the Federal Denominator. In: Kochenov, ed., EUCitizenship and Federalism: The Role of Rights. Cambridge: Cambridge University Press, p. 26 et seq.

15 Cuyvers, A. (2017). General Principles of EU law. In: Ugirashebuja, Ruhangisa, Ottervanger, and Cuyvers, eds., East African Community Law: Institutional, Substantive and Comparative EU Aspects. Leiden: Brill Nijhoff, p. 220.

16 Court of Justice, judgment of 19 November 1991, joined cases C-6/9o and C-9/9o Francovich, para. 30; Court of Justice, judgment of 5 March 1996, joined cases C-46/93 and C-48/93 Brasserie du Pêcheur, paras. 27-36; Court of Justice, judgment of 8 April 2004, joined cases C-293/12 and 594/12 Digital Rights Ireland and Seitlinger and Others, para. 10. Court of Justice, judgment of 19 January 2010, case C-555/o7, Kücükdeveci, para. 21; Court of Justice, judgment of 23 April 1986, case 294/83, Les Verts v. Parliament, para. 12.

18 Kochenov, D. (2011). A Real European Citizenship: A new Jurisdiction Test: A Novel Chapter in the Development of the Union in Europe. Columbia Journal of European Law 18 (1), pp. 56-109, 61; Nic Shuibhne, N. (2010). The Resilience of EU Market Citizenship. Common Market Law Review 47 (6), pp. 1597-1628, 1621 et seq.; Eeckhout, P. (2002). The EU Charter of Fundamental Rights and the Federal Question. Common Market Law Review 39 (5), pp. 945-994, 971; Douglas-Scott, S. (1998). In Search of Union Citizenship. Yearbook of European Law 18 (1), pp. 29-65, 30 et seq.

19 Shaw, J. (2010). Citizenship: Contrasting Dynamics at the Interface of Integration and Constitutionalism. Edinburgh School of Law Working Paper Series No. 14/ 2010, p. 11; 
of 'citizenship cases in which the element of true movement is either barely discernible or non-existent', ${ }^{20}$ while the ratione materiae of EU law has been further stretched to cover virtually hypothetical cross-border situations. ${ }^{21} \mathrm{EU}$ citizenship has further managed to overcome the strict requirement for a crossborder element completely, by creating an independent, EU citizenship-based right, ${ }^{22}$ and redefining the material and personal scope of EU citizenship ${ }^{23}$ to allow more cases to fall within the CJEU's jurisdiction. Most importantly, in Ruiz Zambrano the Court ruled that Article 20 TFEU prevents Member States from taking measures which have the effect of 'depriving EU citizens of the genuine enjoyment of the substance of rights conferred on them by the citizenship of the Union'. ${ }^{24}$ It therefore created the possibility of EU law 'intervening', once the enjoyment of the essence of EU citizenship rights is brought into question. ${ }^{25}$

The restriction on the field of application of the Charter under Article $5^{1}(1)^{26}$ also severely limits the scope of fundamental rights policies, including the relevant jurisdiction for challenges to austerity measures. The Court has not accepted the restriction easily, although it continues to be difficult to predict whether a domestic measure will be found to be bound by the Charter. ${ }^{27}$ The

Spaventa, E. (2008). Seeing the Wood despite the Trees? On the Scope of Union Citizenship and its Constitutional Effects. Common Market Law Review 45 (1), pp. 13-45, 40.

20 Opinion of AG Sharpston delivered on 30 September 2010, case C34/og Ruiz Zambrano; van Eijken, H., and de Vries, S.A. (2011). A New Route into the Promised Land? Being a European Citizen after Ruiz Zambrano. European Law Review 36 (5), pp. 704-721, 710; Tryfonidou, A. (2008). Reverse Discrimination in Purely Internal Situations: An Incongruity in a Citizens' Europe. Legal Issues of Economic Integration 35 (1), pp. 43-67, 50 et seq.; See further: Court of Justice, judgment of 14 October 2008, case C-353/o6, Grunkin and Paul.

21 Court of Justice, judgment of 19 October 2004, case C-200/o2, Zhu and Chen, para. 45; Court of Justice, judgment of 12 July 2005, case C-403/o3, Schempp, para. 47; Court of Justice, judgment of 2 October 2003, case C-148/o2, Garcia Avello, para. 45; Spaventa, E. (2008). Seeing the Wood despite the Trees, cit., p. 21.

22 O'Brien, C. (2016)."Hand-to-mouth" citizenship: decision time for the UK Supreme Court on the substance of Zambrano rights, EU citizenship and equal treatment. Journal of Social Welfare and Family Law 38 (2), pp.228-245, 229 et seq.

23 Rottmann, cit.

24 Court of Justice, judgment of 8 March 2011, case C-34/o9, Ruiz Zambrano, para. 42.

25 Tryfonidou, A. (2008). Reverse Discrimination in Purely Internal Situations, cit., p. 50 et seq.

26 Fontanelli, F. (2014). The Implementation of European Union Law by Member States under Article 51(1) of the Charter of Fundamental Rights. Columbia Journal of European Law 20 (2), pp. 194-247, 193 et seq.

Ibid., p. 193 . 
Court has interestingly interpreted 'implementation' under Article 51(1) broadly as meaning to 'fall within the scope of EU law'. ${ }^{28}$ In Fransson ${ }^{29}$ a remote connection with EU law was enough to trigger the Charter, stressing how much grey area remains in the interpretation of this provision. The scope of EU fundamental rights is therefore interpreted variously, with the Charter being more likely to apply to national rules in cases with a stronger EU interest, while applying only in extreme cases regarding the co-ordination of rules. ${ }^{30}$ Therefore, although the Court has interpreted Article 51(1) broadly, the level of discretion available allows it to promote a differentiated understanding of the Charter's scope of application in selected cases. The vagueness and uncertainty deriving therefrom, ${ }^{31}$ was also criticised by the European Parliament, stating that the citizens' expectations "go beyond the Charter's strictly legal provisions" and called on the Commission to do more to meet citizens' expectations. ${ }^{32}$ Within the framework of strengthening the protection of EU fundamental rights, the Parliament had even proposed the deletion of Article $5^{1}$ of the Charter, ${ }^{33}$ recognising the structural difficulties it creates. A reinforced system, towards a truly constitutionalised Union, could be achieved by adopting a broader and more stable use of the Charter, to make rights more visible to citizens, especially in situations which are firmly within the scope of EU law or have a clear connection with it, such as those of the European Stability Mechanism (ESM).

General principles of EU law are also invoked when 'implementing Union law', in view of the fact that almost all Charter rights have been previously recognised as general principles. ${ }^{34}$ Unlike the Charter, however, due to their hybrid nature, the scope of application of general principles is not as restricted. ${ }^{35}$

28 Court of Justice, judgment of 18 June 1991, case C-26o/89, ERT v. DEP, para. 42; Court of Justice, judgment of 13 June 1996, case C-144/95, Maurin.

29 Court of Justice, judgment of 26 February 2013, case C-617/10, Åkerberg Fransson; Spaventa, E. (2016). The interpretation of Article 51 of the EU Charter of Fundamental Rights: The Dilemma of Stricter or Broader Application of the Charter to National Measures. European Parliament's PETI Committee PE 556.930.

30 Spaventa, E. (2016). The interpretation of Article $5^{1}$ of the EU Charter of Fundamental Rights, cit., p. 10.

31 Fontanelli, F. (2014). The Implementation of European Union Law by Member States, cit., p. 200.

32 European Parliament resolution of 21 January 2016 on the activities of the Committee of Petitions, 2014, (2014/2218(INI)), para. 24.

33 European Parliament resolution of 27 February 2014 on the situation of fundamental rights in the European Union (2012) (2013/2078(INI)), para. 15 .

34 van den Brink, M.J. (2012). EU Citizenship and EU Fundamental Rights: Taking EU Citizenship Rights Seriously. Legal Issues of Economic Integration 39 (2), pp. 273-289, 287.

35 Tridimas, T. (2013). Horizontal Effect of General Principles: Bold Rulings and Fine Distinctions. In: Bernitz, Groussot, and Schulyok, eds., General Principles of EU Law and 
According to AG Bot in his Opinion in Scattolon, the restrictive scope of application defined for the Charter was not intended to restrict the scope of application of the fundamental rights recognised as general principles of EU law, ${ }^{36}$ which can still be invoked where the Charter cannot. Therefore, in terms of the scope of application of the respective instruments, it is argued that a constructivist understanding of EU citizenship can more effectively overcome its restrictions compared to the Charter, demonstrating its greater potential for safeguarding citizens' rights. ${ }^{37}$

\section{The Modern Protection of Fundamental Rights}

To cope with the financial crisis and safeguard financial stability in the euro area, ${ }^{38}$ new mechanisms were adopted, ${ }^{39}$ including the permanent ESM, which was established as an international, intergovernmental Treaty (ESMT) $)^{40}$ concluded and ratified by the Member States outside the EU legal order. Accordingly, Article 136(3) TFEU states that the mechanism is activated if indispensable to safeguarding the stability of the euro area as a whole, subject to strict conditionality, ${ }^{41}$ which is agreed under the relevant memoranda of understanding (MoUs). As a way to alleviate budgetary concerns, conditionality is based on austerity and includes reductions in public spending, cuts in wages

European Private Law. Alphen aan den Rijn: Wolters Kluwer; Lenaerts K., and GutiérrezFons, J.A. (2010). The constitutional allocation of powers and general principles of EU law. Common Market Law Review 47 (6), pp. 1629-1669, 1640; Court of Justice, judgment of 13 July 1989, case 5/88, Wachauf v. Bundesamt für Ernährung und Forstwirtschaft.

36 Opinion of AG Bot delivered on 5 April 2011, case C-108/10, Scattolon, para. 120.

37 Kochenov, D. (2011). A Real European Citizenship, cit., p. 61.

38 Tuori, K. (2014). The Eurozone Crisis: A Constitutional Analysis by Kaarlo Tuori and Klaus Tuori, Cambridge: Cambridge University Press; European Commission (2015). Quarterly Report on the Euro Area. Economic and Financial Affairs 14 (2), p. 28, http://ec.europa. eu/economy_finance/publications/eeip/pdf/ipoo1_en.pdf; Regulation (EU) 407/2010 of the Council of 11 May 2010 on establishing a European financial stabilisation mechanism; Council Document 9614/10 of 10 May 2010, OJ L/118, 12.05.2010, p. 1-4.

39 Rodriguez, P.M. (2016). A missing piece of European emergency law: legal certainty and individuals' expectations in the EU response to the crisis. European Constitutional Law Review 12 (2), pp. 265-293, 270.

40 Treaty Establishing the European Stability Mechanism (ESM) (2012) D/12/3, Recitals 1 and 5 .

41 Opinion of AG Kokott delivered on 26 October 2012, case C-370/12, Pringle, paras. 142-143; Craig, P. (2014). Pringle and the Nature of Legal Reasoning. Maastricht Journal of European and Comparative Law 21 (1), pp. 205-220, 208 et seq. 
and increases in tax revenues. ${ }^{42}$ Although necessary for the mechanism to work, ${ }^{43}$ the conditionality imposed was repeatedly challenged for fundamental rights infringements. ${ }^{44}$ Due to the diversified legal establishment and the use of the financial assistance mechanisms, the judicial challenges have proven arduous, ${ }^{45}$ while the current protection system has been largely ineffective in protecting EU citizens' rights.

The Court has repeatedly referred to the Charter in its rulings, only to conclude in most cases that it cannot be invoked due to a lack of connection with EU law. Therefore, leaving aside the level of protection which could actually have been offered by the Charter, the Court's persistent preference for interpreting Article 51(1) in the narrowest way possible when in fact a connection with EU law could be identified, has led EU citizens to a state of deadlock in such actions. This is primarily the case in claims against the Member States, which are under a duty to implement the agreed conditionality into national laws, in order to restore stability and return to sustainable growth. ${ }^{46}$ The Court in Pringle ${ }^{47}$ and later in Sindicatos dos Bancarios ${ }^{48}$ ruled that the provisions of the Charter do not apply to the implementation of the MoUs for the provision of stability support under the ESM, since the Member States are not implementing Union law within the meaning of Article 51(1) of the Charter. ${ }^{49}$ The

42 Theodoropoulou, S., and Watt, A.(2011). Withdrawal symptoms: an assessment of the austerity packages in Europe. European Trade Union Institute Working papers No. 2/ 2011, p. 11 et seq. 8 .

43 Gilliams, H. (2011). Stress Testing the Regulator: Review of State Aid to Financial Institutions after the Collapse of Lehman. European Law Review 36 (1), pp. 3-25, 5 et seq.; Avalos, H.R.B. (2012). Moral Hazard in the Euro-Zone. MPRA Papers No. 61103, p. 2 et seq.; Pringle, cit., paras. 69 and 111 .

44 Lusiani, N., and Saiz, I. (2014). Safeguarding human rights in times of economic crisis. Council of Europe Commissioner for Human Rights, available at https://rm.coe.int/ safeguarding-human-rights-in-times-of-economic-crisis-issue-paper-publ/16809o8dfa. https://rm.coe.int/168o6daa3f.

45 Kilpatrick, C. (2015). On the Rule of Law and Economic Emergency: The Degradation of Basic Legal Values in Europe's Bailouts. Oxford Journal of Legal Studies 35 (2), pp. 325-353, 331 .

46 Financial Assistance Facility Agreement between European Stability Mechanism and The Republic of Cyprus as the Beneficiary Member State and Central Bank of Cyprus as Central Bank, https://www.esm.europa.eu/sites/default/files/esm_ffa_cyprus_publication_version_final.pdf.

47 Pringle, cit., para. 178.

48 Court of Justice, judgment of 7 March 2013, case C-128/12, Sindicato dos Bancários do Norte and Others.

49 Adam, S., and Mena Parras, F.J. (2013). The European Stability Mechanism through the legal meanderings of the Union's constitutionalism: Comment on Pringle. European Law Review 38 (6), pp. 848-865, 85 o et seq.; Pringle, cit., para. 180. 
Pringle ruling had raised intense debate, since the ESMT, indicates that the EU framework should be observed by the ESM members, especially 'the economic governance rules' set out in the $\mathrm{TFEU},{ }^{50}$ while previous rulings and principles, allowed more room for a connecting link with EU law. ${ }^{51}$

Further reluctance was manifested, in Sindicato Nacional, ${ }^{52}$ where the Court, narrowly ruled that it had no jurisdiction to determine the request for preliminary ruling, since no link with EU law was found. ${ }^{53}$ In contrast, although, the Portuguese Government seemed to 'have gone further than its commitments in the MoU, 54 the national legislation also makes express reference to the Council Decision on granting financial assistance, thus at least a remote link between the national measure with EU law was evident. The Court of Justice was straightforwardly asked about the validity and interpretation of specific provisions implemented in national law in Florescu, ${ }^{55}$ where it had for the first time indicated that since the $\mathrm{MoU}$ is an act of the EU institutions, it must be regarded as implementing that law according to Article 51(1), despite the amount of discretion they have in deciding the implementing measures. ${ }^{56}$ As a whole, the Charter failed to protect EU citizens' rights completely during the financial crisis, primarily because the unstable status of the restriction under Article 51(1) allowed the Courts to treat claims against Member States as purely internal, ${ }^{57}$ even when a remote connection with EU law existed. This approach largely deprived citizens of the ability to proceed in such litigation to the factual assessment of the disputed measures and possible remedies.

50 Beck, G. (2014). The Court of Justice, legal reasoning, and the Pringle case - law as the continuation of politics by other means. European Law Review 39 (2), pp. 234-25o, 240; Hinarejos, A. (2013). The Court of Justice of the EU and the legality of the European Stability Mechanism. Cambridge Law Journal 72 (2), pp. 237-240, 237.

51 Court of Justice, judgment of 12 February 2009, case C-45/o7, Commission v. Greece; Court of Justice, judgment of 20 April 2010, case C-246/o7 Commission v. Sweden, para. 91; Barnard, C. (2013). The Charter, the Court - and the Crisis. University of Cambridge Faculty of Law Research Papers No. 18/ 2013, p. 9.

$5^{2}$ Court of Justice, judgment of 26 June 2014, case C-264/12, Sindicato Nacional dos Profissionais de Seguros e Afins.

53 See also, Court of Justice, judgment of 10 May 2012, case C-134/12, Corpul Naţional al Poliţiştilor.

54 Barnard, C. (2013). The Charter in time of crisis: a case study of dismissal. In: Countouris, and Freedland, eds., Resocialising Europe in a Time of Crisis. Cambridge: Cambridge University Press, p. 262.

55 Court of Justice, judgment of 13 June 2017, case C-258/14, Florescu and Others.

$56 \quad$ Ibid., para. 34 .

57 Kilpatrick, C. (2015). Are the Bailouts Immune to EU Social Challenge Because They Are Not EU Law. European Constitutional Review 10 (3), pp. 393-421, 400. 
The Charter has been more successfully invoked against the acts of the EU institutions tasked with negotiating the MoUs and overseeing the austerity plan. ${ }^{58}$ In her view in Pringle, AG Kokott emphasised that the Commission remains a Union institution and is bound by the full extent of EU law, even when acting within the framework of the ESM. ${ }^{59}$ Accordingly, the Court in Ledra Advertising Ltd stated that the Commission retains within the framework of the ESMT, its role as guardian of the Treaties and should refrain from signing an MoU whose consistency with EU law and the Charter is doubtful. ${ }^{60}$

In contrast, fundamental rights as general principles of EU law have rarely been used, and only recently with any positive effect. Specifically, Associação Sindical dos Juizes Portugueses ${ }^{61}$ questioned the compatibility of austerity measures imposed on the judiciary with the principle of judicial independence. The Court clearly sought to overcome the legal barrier of the Charter by invoking the principle of effective judicial protection under Article 19(1) TEU, since according to the Court, its material scope goes beyond that of Article 47 of the Charter. Although this is a beneficial development for fundamental rights, it is another demonstration of the Charter's weaknesses, forcing the Court to resort to concepts from the pre-constitutionalisation years, where the protection of rights solely depended on general principles. In contrast to the minimal application of the Charter and the general principles, EU citizenship has not played any substantive role in the austerity measures case law. This is primarily due to the limited list of rights attached to it, rendering it irrelevant in such cases, which are grounded in alleged fundamental rights' infringements, thus demoting citizenship from being 'the fundamental status of Union citizens' ${ }^{62}$

The limited applicability of these legal instruments left many wondering how fundamental rights can be among the foundational values of a constitutionalised Union, if their use can be limited more easily than it can be invoked. It has also resulted in a gap in effective judicial protection, because of the limited routes available to access justice, the reluctance of the Courts to support those seeking to minimise the impact of the austerity measures, and finally because the Court's rulings were largely based on reasons unconnected with

\footnotetext{
$5^{8}$ Article 13(3) of the ESM Treaty.

59 Opinion of AG Kokott, Pringle, cit., para. 176; Committee on Constitutional Affairs, Opinion, 11 February 2014, 2013/2277(INI), para. 11.

6o Court of Justice, judgment of 20 September 2016, joined cases C-8/15 P to C-10/15 P, Ledra Advertising v. Commission and ECB, para. 59 .

61 Court of Justice, judgment of 27 February 2018, case C-64/16, Associação Sindical dos Juizes Portugueses; See further, Court of Justice, judgment of 7 February 2019, case C-49/ 18, Escribano Vindel. 
law, but rather with politics. ${ }^{63}$ The reluctance of the Court is arguably based on the nature of the claims under dispute, which include complex economic situations and can have substantial impact on national democracy. ${ }^{64}$ The Court has therefore demonstrated a preference for 'evading' performing legal assessment, rather than embarking on judicial activism, so as to avoid the hostile reaction which would ensue. A disparity in the pursuit of Union objectives is also demonstrated, namely that the Court seems more willing now to act to address the current rule of law crisis and protect the democratic judicial processes at the national and European level, ${ }^{65}$ than it did during the financial crisis. Interest in assessing new routes to equally safeguard citizens' rights and Union's objectives has been prompted, such as the use of EU citizenship in novel areas using the recent 'substance of the rights doctrine'.

\section{The Court's 'substance of the rights' Doctrine}

To tackle the limitations of EU law described above effectively, a broader scope of application of fundamental rights is needed, using a 'living instrument' with transformative qualities, such as the concept of EU citizenship, and the substance of the rights doctrine. Rottmann ${ }^{66}$ in particular has been correctly described as the foundation which paved the way towards the emancipation of EU citizenship from the limits inherent in its free movement origins. ${ }^{67}$ The Court indicated the importance of having due regard to EU law when exercising national powers within the sphere of nationality, ${ }^{68}$ and specifically ruling

63 Tomkin, J. (2013). Contradiction, Circumvention and Conceptual Gymnastics: The Impact of the Adoption of the ESM Treaty on the State of European Democracy. German Law Journal 14 (1), pp. 169-189, 18o et seq.; Repasi, R. (2017). Judicial protection against austerity measures in the euro area: Ledra and Mallis. Common Market Law Review 54 (4), pp. 11231155, 1123 et seq.; Ghailani, D. (2017). Violations of fundamental rights: collateral damage of the Eurozone crisis. In: Vanhercke, Natali, and Bouget, eds., Social policy in the European Union: state of play 2016. Brussels: ETUI, p. 158 et seq.

64 Kriesi, H. (2012). The Political Consequences of the Financial and Economic Crisis in Europe: Electoral Punishment and Popular Protest. Swiss Political Science Review 18 (4), pp. 518-522, 519 et seq.; Funke, M., Schularick, M., and Trebesch, C. (2016). Going to extremes: Politics after financial crises 1870-2014. European Economic Review 88, pp. $227-260,230$.

65 Court of Justice, judgment of 24 July 2018, case C-216/18 PPU, Minister for Justice and Equality.

66 Rottmann, cit.

67 Lenaerts, K. (2015). EU citizenship and the European Court of Justice's 'stone-by-stone' approach. International Comparative Jurisprudence 1 (1), pp. 1-10, 2.

Rottmann, cit., para. 41. 
that where an EU citizen is addressed by a decision withdrawing naturalisation, which causes him to lose the status and the rights conferred by Article 20 TFEU, this falls by reason of its nature and its consequences, within the ambit of EU law. ${ }^{69}$ The citizenship-specific rights which a person would lose are thus emphasised, rather than the general human rights imperative, which indicates a substantial increase in the effect of EU citizenship on national citizenship. ${ }^{70}$

The Ruiz Zambrano case offered further insights into this development and extended the idea that Member States and the EU should leave the substantive core of rights under EU citizenship intact. ${ }^{71}$ In answering the question of whether Article $20 \mathrm{TFEU}$ has an autonomous character and serves as a sufficient connection with EU law, the Court of Justice developed a jurisdictional test, whereby national measures are precluded if depriving EU citizens of the genuine enjoyment of the substance of EU citizenship rights. ${ }^{72}$ Consequently, third-country nationals obtain a derived right to reside in their children's Member State of nationality under Article 20 TFEU when the factual conditions of Ruiz Zambrano are met. ${ }^{73}$ This ruling constitutes one of the most inspiring of the last decade, primarily due to it marking a departure from the traditional cross-border concept, as the Court interpreted Article 20 TFEU as a sufficient link in itself, ${ }^{74}$ consequently extending the scope of application of EU law. Secondly, because the prohibition against a violation of the substance of rights has been applied as a self-standing EU test, ${ }^{75}$ while it had hitherto been applied within the context of the proportionality test. Despite the potentially enormous implications of the doctrine, it has been characterised as frustratingly opaque ${ }^{76}$ since little clarity was provided with regards to the circumstances under which it can be invoked.

Subsequent case law provided further clarity, on the conditions for triggering the recently developed doctrine. It is evident that not every limitation of a

\section{$69 \quad$ Ibid., para. 42.}

70 Shaw, J. (2011). Setting the scene: the Rottmann case introduced. In: Shaw, ed., Has the European Court of Justice Challenged Member State Sovereignty in Nationality Law? EUI Working Papers RSCAS 2011/62, p. 4.

71 Ruiz Zambrano, cit.

72 Ibid., para. 44 .

73 Ibid., para. 45 .

74 van Eijken, H., and de Vries, S.A. (2011). A New Route into the Promised Land, cit., p. 711.

75 van den Brink, M. (2017). The origins and the Potential Federalising Effects of the Substance of Rights Test. In: Kochenov, ed., EU Citizenship and Federalism: The Role of Rights. Cambridge: Cambridge University Press, p. 90 et seq.

76 Lansbergen, A., and Miller, N. (2011). European Citizenship Rights in Internal Situations: An Ambiguous Revolution. European Constitutional Law Review 7 (2), pp. 287-307, 290 et seq. 
right will trigger the doctrine, but only its deprivation. In particular, the Court clarified in McCarthy ${ }^{77}$ that Article $21 \mathrm{TFEU}$ is 'applicable to situations that have the effect of depriving [a Union citizen] of the genuine enjoyment of the substance of the rights' under EU citizenship or of 'impeding the exercise of his right of free movement and residence' within the Member States. ${ }^{78}$ The use of the doctrine, does not thus depend on an EU citizens' age, but rather upon the seriousness of the restraint to the substance of the rights normally conferred. Therefore, a distinction is made whereby the 'impeding effect' refers to the traditional line of case law requiring a cross-border link, without requiring the national measures to cause the loss of the status of Union citizens in practice. ${ }^{79}$ If no cross-border situation occurs, only a deprivation of the substance of the rights will trigger EU law, ${ }^{80}$ requiring the national measure to create more than a 'serious inconvenience'. Moreover, in Dereci, ${ }^{81}$ the Court indicated that the 'deprivation' of the substance of the rights refers to situations in which the Union citizen not only has to leave the territory of the Member State, but the Union territory as a whole. ${ }^{82}$ The strict approach was confirmed in Yoshikazu lida, ${ }^{83}$ where the Court recalled that 'purely hypothetical prospects of exercising the right of freedom of movement' and of that right being obstructed $^{84}$ do not establish a sufficient link with EU law. This stricter approach $^{85}$ emphasised the need to determine whether there is a relationship of dependency with the child's primary carer, ${ }^{86}$ while a major part underlying the Court's reasoning was clearly based on the respect for the division and balance of competences as enshrined in Article 5 TEU. The Court of Justice affirmed in Rendón Marín that the prohibition under Article 20 TFEU, only applies in 'very specific' situations, while this derived right cannot be refused when the

77 Court of Justice, judgment of 5 May 2011, case C-434/o9, McCarthy.

$78 \quad$ McCarthy, cit., para. 56 .

79 Lenaerts, K. (2011). 'Civis Europeus Sum': from the cross-border link to the status of citizen of the Union. Online Journal on free movement of workers within the European Union 3, pp. 6-18, 8 et seq.

8 o McCarthy, cit., para. 56 .

81 Court of Justice, judgment of 15 November 2011, case C-256/11, Dereci and Others.

$82 \quad$ Ibid., para. 66.

83 Court of Justice, judgment of 8 November 2012, case C-4o/11, Iida.

84 Ibid., para. 77 .

85 See further: Court of Justice, judgment of 8 May 2013, case C-87/12, Ymeraga and YmeragaTafarshiku; Court of Justice, judgment of 10 May 2017, case C-133/15, Chávez-Vílchez and Others.

86 Royston, T., and O'Brien, C. (2017). Breathing and not-incarcerated, estranged fathers do not automatically cancel out mothers' Zambrano rights. Journal of Social Security Law 24 (2), pp. D62-D64, D63. 
effectiveness of EU citizenship is to be disregarded. ${ }^{87}$ Therefore, in the Court's view, any possible limitations on the substance of citizenship rights undermine its effectiveness. ${ }^{88} \mathrm{~A}$ de facto loss of a Union citizenship right is thus required, which rightly reduces the consequences of the test without being too intrusive. ${ }^{89}$ Although it is believed that fundamental rights should not be ruled out based on a narrow reading of the Treaties, ${ }^{90}$ the doctrine should be applied only when EU citizenship rights are deprived and cannot be remedied at the national level, to keep the test within the limits of an acceptable federal and legal balance within the EU.

The reasoning of Rottmann was more recently applied in Tjebbes, ${ }^{91}$ confirming the applicability of EU law and competence of the Court to answer the Raad van State's (Council of State) question on the compatibility of Dutch nationality law with the Treaty provisions on EU citizenship, even though the loss of nationality occurred by operation of a law rather than an express individual decision. ${ }^{92}$ The Tjebbes judgment has in fact been even more progressive in intervening into Member State nationality law, both procedurally and substantively, by requiring an individual examination of any decision withdrawing nationality having regard to a set of consequences linked to the status of Union citizenship. While this judicial progression, constitutionalising one of the few areas of executive discretion and dominance, ${ }^{93}$ could constitute the means to effectively protect the legal heritage of EU citizens, the Court followed a rather unexpected logic. Despite the jurisdictional examination, the ruling in Tjebbes tacitly overturns previous caselaw of the Court by holding that EU law does not preclude the withdrawal of EU citizenship based on an ex lege annulment, which comes without warning and based on no wrong-doing. ${ }^{94}$ In other words,

87 Court of Justice, judgment of 13 September 2016, case C-165/14, Rendón Marín, para. 74.

88 Neuvonen, P.J. (2017). EU citizenship and its "very specific" essence: Rendón Marín and CS. Common Market Law Review 54 (4), pp. 1201-1220, 1205 et seq.

89 See further: Ritter, C. (2006). Purely internal situations, reverse discrimination, Guimont, Dzodzi and Article 234. European Law Review 31 (5), pp. 69o-710; Wiesbrock, A. (2012). Disentangling the 'Union Citizenship Puzzle'? The McCarthy Case. European Law Review 36 (6), pp. 861-873; Iglesias Sánchez, S. (2014). Fundamental Rights and Citizenship of the Union at a Crossroads: A Promising Alliance or a Dangerous Liaison? European Law Journal 20 (4), pp. 464-481.

90 D. Kochenov, On Tiles and Pillars: EU Citizenship as a Federal Denominator, in D. Kochenov (ed), EU Citizenship and Federalism, cit., p. 10.

91 Court of Justice, judgment of 12 March 2019, case C-221/17, Tjebbes and others.

92 Ibid., para. 20.

93 S. Coutts, Bold and Thoughtful: The Court of Justice Intervenes in Nationality Case Law: Case C-221/17 Tjebbes, in European Law Blog, 25 March 2019, europeanlawblog.eu. D. Kochenov (2019). The Tjebbes Fail. European Papers 4 (1), pp. 319-336. 
while confirming and even extending the applicability of EU law when examining the loss/acquisition of EU citizenship, the Court regressively made EU citizenship dependent upon the renewal of a passport before its expiration according to the facts of the case.

The judicial establishment of the doctrine, is of great significance, not only concerning its numerous implications, but also in relation to its prospects for further progress and development, towards a more constitutionalised Union. In particular, the judicial activism of the Court of Justice has marked a process of re-delimiting the scope of EU law, through the development of the constructivist nature of EU citizenship, while more meaning and value has been granted to the concept of EU citizenship and the rights attached thereto. More importantly, the 'substance of the rights' doctrine, has expanded the non-exhaustive list, towards including new rights. The 'inter alia clause' under Article 2O(2) TFEU suggests that citizens can enjoy further rights, beyond those expressly stated therein, not only through the procedure enshrined under Article 25 TFEU but also through the judicial incorporation of unwritten rights. ${ }^{95}$ Following the recent judicial developments, the list has indeed been expanded to include new rights, contrary to the allegation of McCarthy that the approach put forward in Ruiz Zambrano was only applicable to the 'rights listed in Article 2O(2) TFEU'.96 This consideration is arguably rather unexpected and inaccurate since the recent series of case law has protected EU citizens' rights not expressly listed in Article $20(2) \mathrm{TFEU}$, such as the right against forced removal from the EU's territory or even the ability to benefit from equality in a wholly internal situation outside the scope of EU law. ${ }^{97}$ It is therefore argued that the extent of Union citizenship rights is much broader than what is defined in a textual sense. ${ }^{98}$

\section{The Way Forward: the 'Internal Applicability of EU Law’ Test}

The recently developed 'substance of the rights' doctrine, seems to have the potential to change the architecture of the fundamental rights protection, towards enhancing the modern protection of EU citizens' rights and overcoming

95 Kochenov, D. (2017). On Tiles and Pillars: EU Citizenship as the Federal Denominator. In: Kochenov, ed., EU Citizenship and Federalism: The Role of Rights, cit., p. 25 et seq.

96 Lenaerts, K. (2011). 'Civis Europeus Sum', cit., p. 9.

97 Court of Justice, judgment of 12 September 2006, case C-300/04, Eman and Sevinger, para. 61; Besselink, L.M. (2008). Annotation of Spain v UK, Eman en Sevinger, and ECtHR Case Seviger and Eman $v$ The Netherlands. Common Market Law Review 45 (3), pp. 787-813.

98 Kochenov, D. (2017). On Tiles and Pillars: EU Citizenship as the Federal Denominator. In: Kochenov, ed., EU Citizenship and Federalism: The Role of Rights, cit., p. 26 et seq. 
the deficiencies identified. This can be done by establishing a connection of the substance of the rights doctrine with the Charter rights and/or the fundamental rights as general principles of EU law, aiming to grant EU citizens a core of rights other than those already listed in Article 20(2).

The proposed way forward, namely the 'internal applicability of EU law' test will be built on two main starting points. It will be firstly based on the idea that the non-exhaustive list under Article 2O(2) TFEU, should always be interpreted in compliance with Article 2 TEU which the Member States are also obliged to comply with. The second starting point is that beyond the scope of Article 51(1) of the Charter, fundamental rights issues are left to national legislation and judiciary, provided that they safeguard the values enshrined under Article $2 \mathrm{TEU}$. The recent developments have, however, allowed some room for EU intervention, in cases that are normally considered as wholly internal and/or as falling outside the scope of EU law. ${ }^{99}$ The proposal brings the classic doctrine a step further, by proposing a three-step jurisdictional test which will allow EU fundamental rights, besides the ones under the list of Article $20 \mathrm{TFEU}$, to be specifically used in purely internal situations. The test particularly involves a judicial incorporation combing a dynamic reading of Article 2 TEU, Article 20 TFEU and the general principles of EU law.

\section{$1 \quad$ First Step: Delimiting the Test in Accordance with Article 2 TEU}

The first step of the test consists in the delimitation of the scope of application of the proposal using Article 2 TEU, in a different way from von Bogdandy's 'reverse Solange'. ${ }^{00}$ This article supports that the 'inter alia clause' under the non-exhaustive list of Article 2O(2) TFEU should be interpreted as including the Union's foundational values, which also work as general legal standards of protection for EU citizens. However, broadening the scope of application of fundamental rights cannot be achieved merely by extending the list of EU citizenship rights already falling within the sphere of the substance of the rights doctrine. It is necessary to focus on cases which require EU intervention by delimiting the scope of application of the proposal to the essential core of rights, which represents the minimum circle of fundamental rights common to the Member States, which cannot be diminished without the right in question losing its value either for the right holder or for society as a whole. ${ }^{101}$ The first step

99 von Bogdandy, A. et al. (2012). Reverse Solange - Protecting the essence of fundamental rights against EU Member States. Common Market Law Review 49 (2), pp. 489-519, 490.

100 Ibid., p. 489.

101 Brkan, M. (2018). The Concept of Essence of Fundamental Rights in the EU Legal Order: Peeling the Onion to its Core. European Constitutional Law Review 14 (2), 
will essentially elaborate this idea through Article $2 \mathrm{TEU}^{102}$ and embody an assessment of the exact content of its values.

Although Article 2 TEU works as a legal standard of assessment, it cannot be interpreted as meaning that the Member States are fully bound by the entire fundamental rights acquis, since this is expressly prevented by the Charter and the Treaty itself. ${ }^{103}$ On the contrary, it aims at safeguarding the essentials which are 'common to the Member States', ${ }^{104}$ covering long-standing national traditions ${ }^{105}$ used by several constitutional courts, and infringements of certain rights which cannot be justified in accordance with the cjeu's case law. ${ }^{106}$ For instance, in Tele 2 Sverige, ${ }^{107}$ the CJEU ruled that the right to freedom of expression (Article 11 of the Charter), constitutes one of the EU's foundational values under Article 2 TEU and it is an essential foundation of a pluralist democratic society.108

The right to effective judicial protection, largely unprotected and exposed during the financial crisis, also falls under Article $2 \mathrm{TEU}$, not only because it constitutes a component of the 'rule of law', but also because it is undoubtedly connected to the 'respect for human rights'. Relatively early in the case law, the Court insisted that the Union is based on the rule of law and has built up in its case law a catalogue of elements inherent to the rule of law, within the meaning of Article $2 \mathrm{TEU},{ }^{109}$ including the principle of separation of powers, ${ }^{110}$ the principle of effective judicial protection ${ }^{111}$ and effective application of EU law. ${ }^{112}$ Consequently, a violation of the rule of law principle under Article 2

pp. 332-368, 340 et seq.; Rivers, J. (2006). Proportionality and Variable Intensity of Review. The Cambridge Law Journal 65 (1), pp. 174-207, 176 et seq.

102 Conclusions of the Presidency of 21-22 June 1993 (SN 180/1/93).

103 Article 51(1) of the Charter and Article 6 TEU.

104 Von Bogdandy, A. et al. (2012). Reverse Solange, cit., p. 500.

105 The need to protect the essence of fundamental rights and not to impose any unjust limitations is expressly enshrined in most of the national Constitutions or EU Charters: Article 19(2) German Basic Law, Article 4(2) Czech Fundamental Rights Charter, Article 8(2) Hungarian Constitution, Article 30(3) Polish Constitution, Article 18(3) Portuguese Constitution, Article 49(2) Rumanian Constitution, Article 13(4) Slovakian Constitution, Article 53(1) Spanish Constitution.

106 von Bogdandy, A. et al. (2012). Reverse Solange, cit., p. 491.

107 Court of Justice, judgment of 21 December 2016, joined cases C-203/15 and C-698/15, Tele 2 Sverige $A B$.

108 Nakanishi, Y. (2018). The EU's Rule of Law and the Judicial Protection of Rights. Hitotsubashi Journal of Law and Politics 46, pp. 1-12, 5 .

109 The term 'rule of law' was enshrined in Article 6 TEU by the Treaty of Amsterdam 1997.

110 Court of Justice, judgment of 10 November 2016, case C-477/16 PPU, Kovalkovas.

111 Court of Justice, judgment of 28 March 2017, case C-72/15, Rosneft; Schrems, cit.

112 Nakanishi, Y. (2018). The EU's Rule of Law and the Judicial Protection of Rights, cit., p. 11; Brkan, M. (2018). The Concept of Essence of Fundamental Rights in the EU Legal 
TEU would likely aggravate a fundamental rights infringement, undermine the basic foundations of the EU legal order and the substantive meaning of Union citizenship. ${ }^{113}$ Such infringements, amounting in their extent and seriousness to the total inexistence of the fundamental right's essence, cannot be adequately remedied within a Member State, but rather at the Union level, through the use of a federalising tool. ${ }^{114}$ However, the use of Article 2 TEU in the proposed test, does not aim to establish its infringement, but is rather used as a safety valve towards including only the 'essentials' within Article 20(2).

\section{$2 \quad$ Second and Third Step: Another Use of Rights}

After defining the essence of Article $2 \mathrm{TEU}$ - delimiting the content eligible to be judicially incorporated into the 'inter alia' list - the next step is to assess the scope of application of the respective Charter right or general principle, to determine its compatibility with the doctrine. The infringement under dispute must finally constitute a deprivation in accordance with the Zambrano doctrine and not a mere inconvenience or impediment, so as to satisfy the proposed test and challenge rights-violating measures outside a strict interpretation of the scope of EU law.

As a result of this divergence in interpretations of Article 51(1), the test's wording is not entirely unambiguous. ${ }^{115}$ The question is thus to what extent the Court of Justice could interpret the scope of the Charter so as to fall within the substance of the rights doctrine. On the one hand, if the 'implementation' concept is adopted according to Akerberg Fransson, ${ }^{116}$ the Charter can be considered applicable in situations 'falling within the scope of EU law' and be invoked in relation to the substance of the rights doctrine. ${ }^{117}$ On the contrary, if the Court cleaves to its narrow interpretation, this does not necessarily prevent the application of EU fundamental rights in purely internal situations, ${ }^{118}$ depending on the extent to which the narrow scope of the Charter can restrain

Order, cit., p 340 et seq.; Court of Justice, judgment of 20 November 2017, case C-441/17, Commission v. Poland; Associação Sindical dos Juizes Portugueses, cit., para. 31.

113 Opinion of AG Poiares Maduro delivered on 12 September 2007, case C-38o/o5, Centro Europa 7, para. 22; Guidance can be drawn from the interpretation given to the criterion of a 'serious and persistent breach' under Article 7(2) TEU.

114 von Bogdandy, A. et al. (2012). Reverse Solange, cit., p. 5 o1.

115 The explanations relating to the Charter of Fundamental Rights (2007) OJ C 303/O2, state that the Charter 'is only binding of the Member States when they act in the scope of Union law'.

116 Åkerberg Fransson, cit.

117 van den Brink, M.J. (2012). EU Citizenship and EU Fundamental Rights, cit., p. 282.

118 Ibid., p. 287. 
the scope of those general principles as well. ${ }^{119}$ The prevailing view in this article is that the scope of application of the Charter is narrower than that of general principles of EU law and the narrow scope of the former cannot affect that of the latter.

After the pragmatic Opinion of AG Bot in Scattolon, ${ }^{120}$ the Court in Associação Sindical dos Juizes Portugueses clarified that Article 19(1) TEU can be applied in full, even if the Charter does not apply, in a far-reaching demonstration of the Court's judicial activism in favour of European integration..$^{21}$ It is therefore safe to say that at least in the case of effective judicial protection, general principles of EU law have a broader scope of application than the Charter rights, with the latter not affecting the former's application. Accordingly, the argument put forward by AG Mengozzi that the Charter prevents the inclusion of EU fundamental rights in the substance of the rights doctrine is not entirely correct, ${ }^{122}$ or at least is not the only possible explanation. That being the case and due to the complexity of the Charter's scope, fundamental rights as general principles are more likely to be found eligible to be included in the substance of the rights doctrine as part of the new jurisdictional test.

\section{3} The Paradigm of Effective Judicial Protection

A link between fundamental rights as general principles of EU law and the substance of the rights doctrine is accordingly attainable, provided that the relevant principle of EU law is an 'essential' under Article 2 TEU and its scope of application is broader than that of Article 20 TFEU. Although this possibility is arguably achievable for several principles, that of effective judicial protection is the most suitable for examination, since it has been a vulnerable and constantly-violated right during the recent financial crisis, and recent judicial developments have substantially added to its significance. ${ }^{123}$

The concept of 'effectivejudicial protection' is dual-faced, occasionally referred to by the Courts as a self-standing 'principle'124 of EU law or as a 'fundamental

\footnotetext{
119 Editorial Comments (2010). The Scope of Application of the General Principles of Union law: An Ever Expanding Union. Common Market Law Review 47 (6), pp. 1589-1596, 159 o.

120 Opinion of AG Bot, Scattolon, cit., para. 120.

121 Associação Sindical dos Juízes Portugueses, cit., para. 29.

122 Opinion of AG Mengozzi delivered on 29 September 2001, case C-256/11, Dereci and Others, paras. $37-39$.

123 Alston P., and Weiler, J.H.H. (1999). An 'Ever Closer Union' in Need of a Human Rights Policy: The European Union and Human Rights. In: Alston, ed., The EU and Human Rights. Oxford: Oxford University Press, p. 200.

124 Court of Justice, judgment of 25 July 2002, case C-50/oo P, Unión de Pequeños Agricultores v. Council, para. 39; Court of Justice, judgment of 1 April 2004, case C-263/o2 P, Commission
} 
right' under the Charter. ${ }^{125}$ It inter alia entrusts the responsibility to ensure judicial review in the EU legal order both to the Court of Justice and to the national courts and tribunals. ${ }^{126}$ As discussed above, the Court made clear in Associação Sindical dos Juizes Portugueses that the scope of application of Article 19 TEU is broader than that of Article 47 of the Charter. ${ }^{127}$ Through a particularly interesting legal reasoning, the Court built on 'operationalising' Article 2 TEU, by stating that Article $19 \mathrm{TEU}$, 'gives concrete expression to the value of the rule of law'.128 Without offering any explanation on the applicability of the Charter, the Court overcame the barrier in Article 51(1) and exclusively relied on Article 19(1) TEU, merely by requiring the existence of a virtual link between the relevant national measures and EU law and thus enabled natural and legal persons to challenge a broader set of national measures using this route. ${ }^{129}$ This ruling has created a national legal obligation to safeguard judicial independence based on a combined reading of Articles 2, 4(3) and 19(1) TEU, regardless of whether the situation falls within the scope of EU law. The judgment has far-reaching consequences for effective judicial protection, since the Court went beyond the minimum effective necessity of the national remedies needed to ensure the application of EU law and gave the green light to proceed with the proposed jurisdictional test. ${ }^{130}$

The new approach towards Article $19 \mathrm{TEU}$, is believed to have a great resemblance with the substance of the rights doctrine, since both were developed by the Court of Justice as the main actor, through the exercise of judicial activism. Moreover, they aimed to overcome the barrier created by the restricting provision of the Charter's scope, while at the same time, both resulted in the enhancement of citizens' rights protection. There are however significant dissimilarities between them, namely the substance of the rights doctrine constitutes a tool for claiming EU legal jurisdiction, which is only triggered when

v. Jégo-Quéré, para. 29; Court of Justice, judgment of 16 July 2009, case C-12/o8, Mono Car Styling, para. 46 .

125 Court of Justice, judgment of 29 January 2009, case C-275/o6, Promusicae, para. 62; Leczykiewicz, D. (2010). 'Effective Judicial Protection' of Human Rights After Lisbon: Should National Courts be Empowered to Review EU Secondary Law. European Law Review 35 (3), pp. 326-348, 33 o.

126 Nic Shuibhne, N. (2013). The Coherence of EU Free Movement Law: Constitutional Responsibility and the Court of Justice. Oxford: Oxford University Press.

127 Associação Sindical dos Juizes Portugueses, cit., para. 32.

128 Ibid., paras. 29-38.

129 Ibid., paras. 27-29; Pech, L., and Platon, S. (2018). Rule of Law backsliding in the EU: The Court of Justice to the rescue? Some thoughts on the ECJ ruling in Associação Sindical dos Juízes Portugueses. EU Law Analysis, available at http://eulawanalysis.blogspot.com. cy/2018/o3/rule-of-law-backsliding-in-eu-court-of.html.

130 Pech, L., and Platon, S. (2018). Rule of Law backsliding in the EU, cit. 
a deprivation of the genuine enjoyment of the substance of the rights under Article 20 TFEU occurs. ${ }^{131}$ It can thus be characterised as a moderately invasive approach, which must be used as a last resort to preserve the effectiveness of EU law. In contrast, the development of Article 19(1) $\mathrm{TEU}^{132}$ constitutes a new general obligation, regardless of whether the matter falls within the scope of EU law. It is therefore more invasive, since it essentially created a federal standard of review for the principle of judicial independence that can now be directly invoked before national courts, demonstrating that the Court of Justice does not hesitate to issue courageous decisions to secure EU law. ${ }^{133}$

This article proposes a practical tool for claiming jurisdiction under EU law, rather than a general obligation, to enable the review of national breaches of the rule of law occurring outside the areas covered by the EU's acquis. Beyond the scope of the Charter, applicants challenging austerity measures have not been able successfully to invoke EU fundamental rights, although numerous assistance packages were clearly granted through EU-established mechanisms, unless the substance of the rights doctrine were triggered and the matter were brought within the scope of EU law. According to the current proposal, if an infringed right whose substance had been deprived by a national measure was not expressed within the list of Article 20(2), the 'inter alia' clause applies, suggesting that citizens can also enjoy the protection of other rights. ${ }^{134}$ The delimitation of the 'eligible' rights is best achieved using Article 2 TEU, without aiming to establish its infringement, but it is rather used as a boundaries-indicator. Subsequently, the scope of application of the respective Charter right or general principle, is assessed to determine its compatibility with the doctrine.

\section{Concluding Remarks}

Recent judicial developments, including the substance of the rights doctrine, have built on the constitutional perspective of EU citizenship, ${ }^{135}$ by inter alia

\footnotetext{
131 Ruiz Zambrano, cit., para. 44.

132 Associação Sindical dos Juizes Portugueses, cit.

133 Taborowski, M. (2018). CJEU Opens the Door for the Commission to Reconsider Charges against Poland. Verfassungsblog, available at https://verfassungsblog.de/cjeu-opens-thedoor-for-the-commission-to-reconsider-charges-against-poland/.

134 See, Eeckhout, P. (2002). The EU Charter of Fundamental Rights, cit., p. 980 et seq.; Da Cruz Vilaça, J.L., and Silveira, A. (2017). The European Federalisation Process and the Dynamics of Fundamental Rights. In: Kochenov, ed., EU Citizenship and Federalism, cit., p. 133 et seq.

135 Hailbronner K., and Thym, D. (2011). Case C-34/o9, Gerardo Ruiz Zambrano v. Office national de l'emploi (ONEm). Common Market Law Review 48 (4), pp. 1253-1270.
} 
proving that the list of rights the Treaties express is not exhaustive, but can rather incorporate 'unwritten' rights. ${ }^{136}$ More importantly, they have granted further opportunities for reinforcing EU fundamental rights protection, such as the proposed expansion of the substance of the rights doctrine towards including the principle of effective judicial protection, when a deprivation of the substance of the rights under the principle of effective judicial protection occurs. Nevertheless, strong objections against such a proposal can be raised. The proposed expansion of the doctrine can easily be perceived as a threat to the system of allocation of competences. However, no such contradiction occurs, because Article $2 \mathrm{TEU}$ is employed as a safety valve, confining the expansion of the proposal with the requirement for a deprivation of the substance of the rights, which safeguards national identities, provided that the foundations and the effectiveness of EU law are not eroded.

Moreover, conflicts with other Treaty provisions can emerge, including with Article 25(2), which allegedly prevents the desired judicial incorporation of fundamental rights into citizenship status. However, this does not constitute an absolute obstacle to judicial incorporation, since the procedural limitations are read as applying to the legislature only, ${ }^{137}$ thus ensuring the constitutional legitimacy of a judicial incorporation. The use of Article 2 TEU could also raise arguments that the 'values on which the Union is built' are illusory in a number of respects. ${ }^{138}$ Although an acquis on values would give it more weight, the increasing use of the provision in the Court's case law proves the opposite. ${ }^{139}$ Moreover, no conflict with Article 7 TEU can arise, since the proposal is not intending to turn Article 2 TEU into black-letter law or establish its violation, but rather to 'operationalise' it, by shaping the essence of the values expressed therein, which also constitute basic rights to be enjoyed by EU citizens. ${ }^{140}$

136 Kochenov, D. (2013). The Essence of EU Citizenship Emerging from the Last Ten Years of Academic Debate: Beyond the Cherry Blossoms and the Moon? International and Comparative Law Quarterly 62, pp. 97-136, 100.

137 Düsterhaus, D. (2017). EU Citizenship and Fundamental Rights: Contradictory, Converging or Complementary. In: Kochenov, ed., EU Citizenship and Federalism, cit., p. 643 et seq.

138 Kochenov, D. (2013). On Policing Article 2 TEU Compliance - Reverse Solange And Systemic Infringements Analyzed. Polish Yearbook of International Law 33, pp. 145-170, 150 et seq.

139 Associação Sindical dos Juizes Portugueses, cit.; General Court, judgment of 3 February 2017, case T-646/13, Minority SafePack - one million signatures for diversity in Europe v. Commission; Court of Justice, order of 17 July 2014, case C-505/13, Yumer; Court of Justice, order of 12 June 2014, case C-28/14, Pańczyk; General Court, judgment of 10 May 2016, case T-529/13, Izsák and Dabis v. Commission.

140 Kochenov, D. (2013). On Policing Article 2 TEU Compliance, cit., p. 16o. 
All in all, the proposal is fully in line with the doctrinal and jurisprudential approaches towards Union citizenship and will arguably allow citizens facing effective judicial protection violations, including those faced during the financial crisis, to bring their cases within the scope of EU law, provided that the requirements described above are satisfied. Further rights can also be protected through this proposal if the test is satisfied, with equality and non-discrimination rights constituting the most likely candidates, considering that during the crisis, the disputed measures were commonly challenged before the Court as being discriminatory and that the general principle of nondiscrimination has long been established within the EU legal order. Although the proposal's reach is limited, it would definitely overcome the barrier imposed by Article 51(1) of the Charter and safeguard the 'substance' of the 'essential' rights which must be included in the list of EU citizenship rights. It is also believed that such an incorporation in practice would prompt the Court to be more willing to claim jurisdiction, while the current imbalance between the EU's purposes would be largely restored, by acknowledging that the enjoyment of rights continued to lie at the heart of the EU, even during the financial crisis. 